\title{
Dementia and Geriatric Cognitive Disorders
}

Vol. 22, No. 3, $2006 \quad$ August 2006

原著論女

185 認知症患者の死亡率

Incident Dementia Cases and Mortality

Gühne, U. ; Matschinger, H. ; Angermeyer, M.C.; Riedel-Heller, S.G.

Dement Geriatr Cogn Disord 2006;22:185-193 (DOI:10.1159/000094786)

Free Abstract Article (References) Article (PDF $237 \mathrm{~KB}$ )

PPV price: USD 25

194 前頭葉側頭葉変性症において MMSE 得点の減少率はアルツハイマー病よりも大きい

Chow, T.W. ; Hynan, L.S. ; Lipton, A.M.

Dement Geriatr Cogn Disord 2006;22:194-199 (DOI:10.1159/000094870)

Free Abstract Article (References) Article (PDF $183 \mathrm{~KB}$ )

PPV price: USD 25

200 パーキンソン病認知症患者脳春髄液における $\beta$ アミロイド 1-42 とタウ蛋白

Mollenhauer, B. ; Trenkwalder, C. ; von Ahsen, N. ; Bibl, M. ; Steinacker, P. ;

Brechlin, P. ; Schindehuette, J. ; Poser, S. ; Wiltfang, J. ; Otto, M.

Dement Geriatr Cogn Disord 2006;22:200-208 (DOI:10.1159/000094871)

Free Abstract Article (References) Article (PDF $228 \mathrm{~KB}$ )

PPV price: USD 25

209 高齢者において順行性の記銘力から順行性記憶障害の訴えを予測する

Zeintl, M. ; Kliegel, M. ; Rast, P. ; Zimprich, D.

Dement Geriatr Cogn Disord 2006;22:209-215 (DOI:10.1159/000094915)

Free Abstract Article (References) Article (PDF $163 \mathrm{~KB}$ )

PPV price: USD 25

216 日本における剖検により確認されたアルツハイマー病とレビィ小体認知症における $B D N F$ 遺伝子変異

Akatsu, H. ; Yamagata, H.D. ; Kawamata, J. ; Kamino, K. ; Takeda, M. ; Yamamoto, T. ; Miki, T. ; Tooyama, I. ; Shimohama, S. ; Kosaka, K.

Dement Geriatr Cogn Disord 2006;22:216-222 (DOI:10.1159/000094933)

Free Abstract Article (References) Article (PDF $150 \mathrm{~KB}$ )

PPV price: USD 25 
223 軽度認知障害(MCI)における海馬と脳梁における Water Diffusivity $の$ 局所増加パターン

Wang, H. ; Su, M.-Y.

Dement Geriatr Cogn Disord 2006;22:223-229 (DOI:10.1159/000094934)

Free Abstract Article (References) Article (PDF $444 \mathrm{~KB}$ )

PPV price: USD 25

230 認知症における自律神経症状の有病率と体力、ADL と QOL との相関

Allan, L. ; McKeith, I. ; Ballard, C. ; Kenny, R.A.

Dement Geriatr Cogn Disord 2006;22:230-237 (DOI:10.1159/000094971)

Free Abstract Article (References) Article (PDF $243 \mathrm{~KB}$ )

PPV price: USD 25

238 家族性アルツハイマー病における認知機能障害はプレセニリン 2 遺伝子 M239V 変異に相関する

Giovagnoli, A.R. ; Marcon, G. ; Giaccone, G. ; Confaloni, A.M. ; Tagliavini, F.

Dement Geriatr Cogn Disord 2006;22:238-243 (DOI:10.1159/000094972)

Free Abstract Article (References) Article (PDF 176 KB)

PPV price: USD 25

244 集団における研究において認知症の診断を再考する :

アルツハイマー病とは? 血管性認知症とは?

Agüero-Torres, H. ; Kivipelto, M. ; von Strauss, E.

Dement Geriatr Cogn Disord 2006;22:244-249 (DOI:10.1159/000094973)

Free Abstract Article (References) Article (PDF $223 \mathrm{~KB}$ )

PPV price: USD 25

250 作業記憶の活性化でみられる $\theta$ 同期の減少は進行性軽度認知障害(MCI) と相関する

Missonnier, P. ; Gold, G. ; Herrmann, F.R. ; Fazio-Costa, L. ; Michel, J.-P. ;

Deiber, M.-P. ; Michon, A. ; Giannakopoulos, P.

Dement Geriatr Cogn Disord 2006;22:250-259 (DOI:10.1159/000094974)

Free Abstract Article (References) Article (PDF $288 \mathrm{~KB}$ )

PPV price: USD 25

総説

260 アルツハイマー病における妄想の治療一薬物治療への反応

Fischer, C. ; Bozanovic, R. ; Atkins, J.H. ; Rourke, S.B. ;

Dement Geriatr Cogn Disord 2006;22:260-266 (DOI:10.1159/000094975)

Free Abstract Article (References) Article (PDF 176 KB)

PPV price: USD 25 